UDC 621.83

M. Margulies, DSc, Prof., Y. Gordienko

Pryazovskyi State Technical University, 7 Universytets'ka Str., Mariupol, Ukraine, 87500, e-mail: mmargulis@mail.ua, extremo1981@gmail.com

\title{
EXPERIMENTAL RESEARCH OF FORCE WAVE PRECESSION GEARS WITH ROLLING ELEMENT
}

М.В. Маргуліс, Я.О. Гордієнко. Експериментальні дослідження силової хвильової прецесійної передачі 3 тілами кочення. Підвищення якості та надійності машин і механізмів при одночасному зменшенні їх масових та габаритних параметрів і підвищення економічності є основним завданням сучасного машинобудування. Відомо, що хвильові передачі 3 тілами кочення $є$ найбільш економічним різновидом хвильових передач за масовими та габаритними параметрами і ККД. Це досягається заміною хвильового зубчастого зачеплення кульовим, яке практично виключає тертя ковзання і підвищує ККД (за рахунок виключення втрат в хвильовому зубчастому зачепленні і генераторі хвиль) і надійність передачі (за рахунок виключення гнучких ланок). Метою виконаної роботи було проведення експериментальних досліджень нового дослідницько-промислового зразка хвильової прецесійної передачі 3 тілами кочення 3 метою підтвердження актуальності виконаних теоретичних досліджень і практичного відпрацювання рекомендацій щодо раціонального конструювання нових хвильових прецесійних передач 3 тілами кочення. На підставі розроблених рекомендацій по створенню хвильової прецесійної передачі 3 тілами кочення був спроектований і виготовлений механізм 3 оптимізованими конструктивними і технологічними параметрами, який успішно пройшов стендові випробування, в процесі яких була підтверджена працездатність механізму, визначені його ККД, температурні, вібраційні і шумові характеристики, а також виконані випробування на довговічність. Використання розробленої конструкції хвильової прецесійної передачі 3 тілами кочення дозволяє: до 2,7 рази знизити матеріаломісткість передавальних механізмів в порівнянні 3 традиційними зубчастими передачами; забезпечити більш надійну працездатність в порівнянні з хвильовими зубчастими передачами за рахунок виключення гнучкого ланки; забезпечити підвищення навантажувальної здатності механізму до 30 \% в порівнянні з існуючими хвильовими передачами з тілами кочення. На підставі результатів експериментальних досліджень хвильової прецесійної передачі 3 тілами кочення отримали подальший розвиток основи міцністного розрахунку з оптимізацією конструктивних параметрів за критеріями мінімальних контактних напружень і рівномірності руху тіл кочення вздовж періодичних доріжок кочення. Проведені експериментальні дослідження розробленого механізму підтвердили правомірність використання розроблених рекомендацій по конструюванню і технології виготовлення при створенні серійних аналогічних приводів 3 високими техніко-економічними показниками.

Ключові слова: хвильова передача, періодична доріжка кочення, тіло кочення, кут нутації, ковзання, оптимізація, прецесія

M. Margulies, Y. Gordienko. Experimental research of force wave precession gears with rolling element. The main task of modern mechanical engineering is to improve the quality and reliability of machinery and mechanisms while reducing their overall dimensions and increasing cost-effectiveness. Wave gears with rolling element are known to be the most efficient type of wave gears in terms of weight, dimensions and efficiency factor. This is achieved by replacing the wave gearing with the spherical engagement which eliminates sliding friction and increases the efficiency factor (due to the exclusion of losses in the wave gearing and wave generator) and gear reliability (due to the exclusion of flexible links). The purpose of the work is to perform experimental research of the new industrial prototype of wave precession gear with rolling element in order to confirm the importance of the performed theoretical studies and practical recommendations developed for the rational engineering of new wave precession gears with rolling element. On the basis of the developed recommendations for the production of wave precession gears with rolling element, a mechanism with optimized design and technological parameters has been engineered and manufactured; it has successfully passed bench tests, during which the efficiency of the mechanism has been confirmed, its efficiency, temperature, vibration and noise tests as well as performance tests have been performed. The use of the design developed for wave precession gears with rolling element allows: (a) reduce material consumption of gears in comparison with traditional gears up to 2.7 times; (b) provide more reliable performance in comparison with wave gears by eliminating the flexible link; (c) ensure the increase of the loadcarrying capacity of the mechanism by up to $30 \%$ in comparison with existing wave gears with rolling element. On the basis of the results of experimental research for wave precession gears with rolling element, further strength calculations of wave precession gears with rolling element has been developed with optimization of design parameters according to the criteria of minimum contact stresses and uniform motion of rolling element along the periodic roller path. The experimental research of the developed mechanism with wave precession gears with rolling element confirmed the proper use of the developed recommendations on design and manufacturing technology in terms of serial production of similar drives with high technical and economic indicators.

Keywords: harmonic drive, periodic race groove, rolling element, nutation angle, sliding motion, optimization, precession

\section{Introduction}

The development of modern mechanical engineering puts in a number of priority tasks a constant increase of capacities and reduction of mass-dimensional indicators, concentrated in single machines or units.

\section{DOI: 10.15276/opu.1.60.2020.02}

(C) 2020 The Authors. This is an open access article under the CC BY license (http://creativecommons.org/licenses/by/4.0/). 
Successful creation of a new high-efficiency technique depends on providing it with a reliable and durable drive, the most laborious part of which is the mechanism of conversion of speed and output moment - a reducer or a multiplier. The variety of requirements made by different consumers for gearboxes is reduced, in the main, to an increase in reliability and durability, efficiency and load capacity while reducing their weight, overall dimensions and cost of manufacture. The leading place among the mechanical gears used in the drives of the machines is occupied by non-wave gears, for which, with increasing load capacity, there is a significant increase in overall dimensions and material capacity, and in large gear ratios, a decrease in efficiency.

Complex satisfaction of these requirements with partial improvement of traditional gears becomes less effective. Therefore, the problem of creating new types of gears and mechanical gears is particularly urgent and requires fundamentally new design solutions.

The known wave gears have the following advantages over gears: a larger gear ratio in one step (up to 455); high load capacity due to multi-pair contact of teeth at comparable gear sizes; high efficiency $(0.80 \ldots 0.90)$ due to the low speeds and relative displacements of the teeth in the wave gearing.

The known wave gears have a number of advantages over gears: a larger gear ratio in one stage (up to 455); high load capacity due to multi-pair contact of teeth at comparable gear sizes; high efficiency $(0.80 \ldots 0.90)$ due to the low speeds and relative displacements of the teeth in the wave gearing. The use of wave gears in the drives of heavily loaded machines allows to reduce by $1.5 \ldots 2.5$ times the overall dimensions of the actuators and supports under the actuators, as well as to reduce dynamic loads by $30 \ldots 40 \%$ due to the reduced torsional rigidity of the flexible gear wheel with similar operational characteristics [1]. The main disadvantage of wave gearing is the presence of a flexible gear wheel. This wheel is a thin-walled sheath, operating in heavy duty mode with alternating bending loads. The possible fatigue failure of the flexible gear wheel is the most likely cause of the failure of the wave gearing, which imposes limitations on reliability and durability. The manufacture of flexible gears requires the use of high quality steels with strict requirements for the presence of internal defects and special heat treatment. The low manufacturability of the production of flexible gear wheels is due to the use of special individual technological equipment and low coefficient of material use, which significantly increases the cost of production.

Currently, active research, development and development of mechanisms of motion conversion, using gears not in the gearing, but in the types of gearing, in which the torque transmission is carried out by means of rolling element, balls or rollers moving in periodic rolling tracks, are underway.

Exclusion from the wave gearing of a flexible link and its replacement by functional purpose on a rolling body and periodic paths of a swing allows to increase reliability and to reduce the complexity of manufacturing of similar gears in terms of operational parameters, while maintaining all the advantages of wave gearing, which is why working.

\section{Analysis of recent publications and problem statement}

At the moment, on the basis of Tomsk Polytechnic University, wave transmissions with intermediate rolling element are being actively developed and investigated [2 - 9]. A significant contribution to the theoretical and experimental study of gears with rolling element was made by professors A. Belyaev [10] and R. M. Ignatishchev [11], I. A. Bostan [12]. However, the existing works cannot be used to assess the performance of the proposed new wave gears with rolling element due to significant differences in the kinematics of gears and the geometry of the main links (a significant difference in the spatial trajectories of the periodic race grooves, as well as the designs of the nodes of the main links), which caused theoretical and subsequent experimental studies of a new transmission design with rolling element [13].

\section{The purpose and objectives of research}

The aim of this work was to conduct experimental studies of a new pilot industrial model of wave precession transmission with rolling element (WPGRE) [13] in order to confirm the relevance of the theoretical studies and practical development of recommendations for the rational design and manufacturing technology of new WPGRE.

To achieve this goal, the following series of tasks were solved: 
- an analysis of modern manufactured structures and research on gears using rolling element to transmit torque was performed;

- developed a new rational design of WPGRE;

- recommendations were developed for calculating the geometric parameters of the main links of the WPGRE [14];

- developed a rational technology for the manufacture of the main parts of WPGRE [15];

- a workable prototype industrial design of WPGRE and a test bench were manufactured;

- bench tests of the WPGRE model were carried out according to the main operational indicators.

\section{Statement of the main material}

The pilot industrial design of WPGRE was manufactured and tested at the machine-building enterprise MAGMA LLC in Mariupol in accordance with our developed methodology.

The transmission gear under study (Fig. 1) contains: an input shaft 1 mounted on radial bearings 3 , based on a threaded cover 4 and an output shaft 6 ; thrust roller bearings 2 mounted on the eccentric journals of the input shaft 1 , which interact with the precession wheel 11; output shaft 6 mounted on tapered angular contact bearings 7, based in a glass 8 , rigidly connected to the housing 5; an intermediate wheel 9 connected by a spline connection to the output shaft 6; an intermediate wheel 10 connected by a spline connection to the housing 5; balls 12 located in the holes of the separators 13 . Balls 12 are based on the surface of the MPC, made on the outer spherical surface of the precession wheel 11 and the inner spherical surfaces of the intermediate wheels 9 and 10 . The precision wheel 11 is mounted on bearings 2 , with the possibility of making rotational and translational axial movements, providing self-alignment of the input shaft 1 in the axial direction.
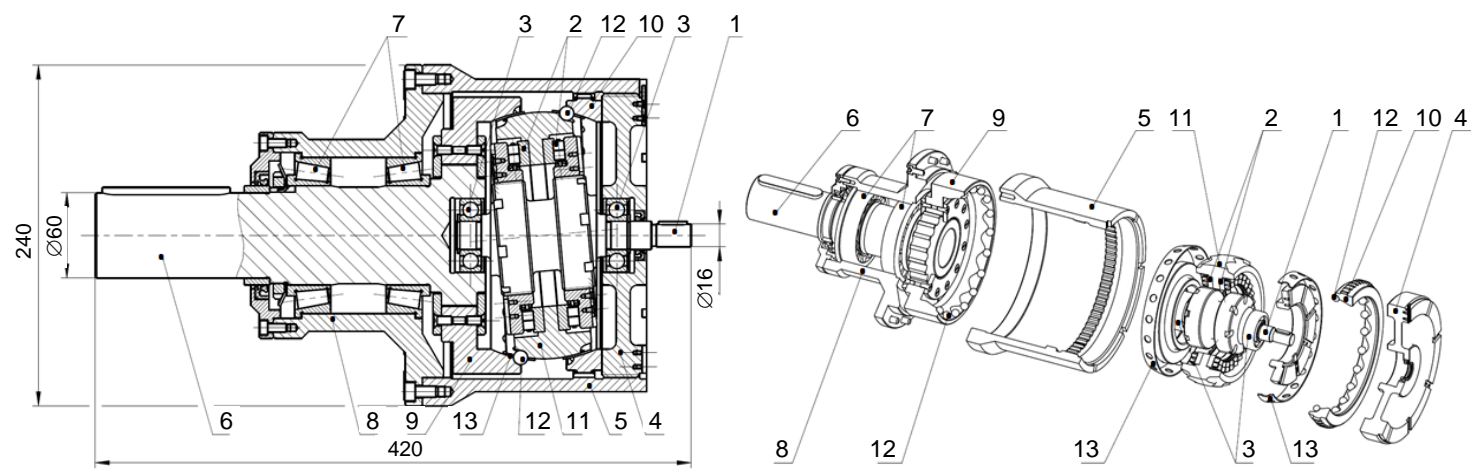

Fig. 1. Transmission gear under study with a two-stage WPGRE: 1 - input shaft, 2 - thrust bearing, 3 - radial bearing, 4 - cover, 5 - housing, 6 - output shaft, 7 - bearings, 8 - glass, 9 - intermediate wheel, 10 intermediate wheel, 11 - precession wheel, 12 - balls, 13 - separator

This mechanism operates as follows. When the input shaft 1 is rotated through the thrust bearings 2 , the precession movement of the precession wheel 11 is excited. Two symmetrically arranged periodic race grooves are made on the outer spherical surface of the precession wheel, one of which interacts via balls 12 with periodic race grooves made on the inner spherical surface of the stopped the intermediate wheel 10, and the other with a periodic raceway made on a rotating intermediate wheel 9 .

The intermediate wheel 10 is fixedly mounted in the housing 5 . The intermediate wheel 9 is connected to the output shaft 6 motionless, which ensures the transmission of torque. The difference in the numbers of periods of the periodic raceway of the precession wheel 11 and the intermediate wheel 10 provides rotation with reduction of the precession wheel 11 . The difference in the numbers of periods of the periodic raceway of the precession wheel 11 and the intermediate wheel 9 provides rotation with reduction of the intermediate wheel 9. The rotation speed of the output shaft 6 is determined by the algebraic sum of the rotational speeds of the precession wheel 11 and the intermediate wheel 9 relative to the precession.

Experimental studies were conducted to determine the compliance of its calculated and actual characteristics and identify possible design flaws for their subsequent elimination. 
Specifications of developed WPGRE:

- maximum torque on the output shaft, Nm 2500

- gear ratio 100

- number of steps 2

- frequency of rotation of the input shaft of the gearbox, rpm 1500

The mass of the gearbox, $\mathrm{kg} \quad 70$

In the process of bench testing, the following transmission characteristics were investigated:

- performance in operating modes,

- coefficient of performance

- the presence of wear of the periodic raceway after a test cycle under loads,

- temperature condition

- noise level,

- durability.

The study of the main parameters of the WPGRE pilot industrial model was carried out by observing, recording and analyzing the results of experiments in the bench operating conditions of the transmission.

In order to evaluate the performance of the WPGRE links in the research process, reverse loading (smooth and stepwise) was carried out under steady and transient operating conditions. The main characteristics of WPGRE were determined at steady loads and rotational speeds.

During the initial tests, the transmission kinematics was verified and the theoretical methodology of the kinematic calculation was confirmed.

The test bench developed by us for testing a pilot industrial design WPGRE (Fig. 2) contains a drive motor 1, powered by a frequency converter, the output shaft of which is connected through an elastic coupling 2 to the gearbox under test with VPGRB 3, the output shaft of which is connected through a gear coupling 4 to a pair of gear gearboxes 5 and 6, connected by a gear clutch 7 and operating in multimultiplier mode. The output shaft of the second gearbox through the second elastic coupling 8 is connected to the shaft of the generator 9 with a frequency converter.

The efficiency was determined by the ratio of the electrical parameters on the WPGRE drive motor and the generator installed as a load element on the side of the WPGRE output shaft through two multipliers (the method of measuring electric power). Previously, prior to testing, the efficiency of all the constituent elements of the stand involved in the transmission of torque for their consideration in calculating the efficiency of the mechanism was determined by a similar method.

The measurement of electrical parameters was performed by a three-phase energy recorder PEL103 No. 166486 PKH.

\section{Research results}

The efficiency study was carried out with a torque on the output shaft and the rotation speed of the input shaft in the range: $T_{\text {out }}=0 \ldots 2500 \mathrm{~N} \cdot \mathrm{m} ; V_{\text {in }}=300,500$, 750, 1000, 1250, $1500 \mathrm{rpm}$.

At the beginning of the tests, the gearbox was run in idle (about 10 hours) and run-in under load. The criterion of running-in transmission was adopted the condition for obtaining a stable efficiency. The gear running-in process took about 20 hours.

The increase in the efficiency of the mechanism under study during its running-in can be explained by

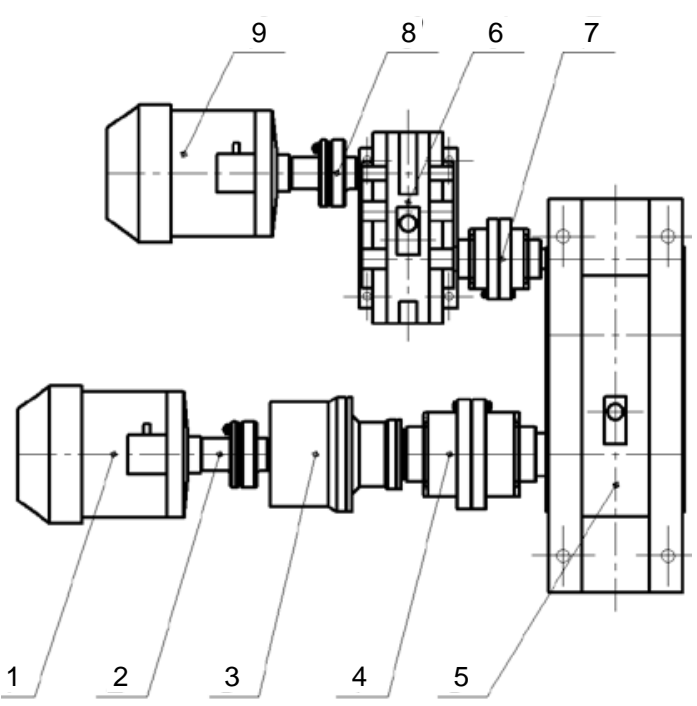

Fig. 2. Scheme of the test bench for WPGRE: $1-$ electric motor, 2 - coupling MУВП 250, 3 gearbox with WPGRE, 4 - gear coupling M3 6300, 5 - gearbox Ц2У-250; 6 - gearbox 2Ц2$100 H, 7$ - clutch gear M3 1600, 8 - clutch МУВП 250, 9 - generator 
the elimination of the initial edge contact of the periodic race grooves with the rolling element, revealed during repeated disassemblies of the WPGRE.

Subsequent verification of changes in the efficiency of the mechanism after 400 hours of operation at the stand showed that it increased and amounted to $80 \%$ at a load of $2500 \mathrm{Nm}$, and an input shaft rotation frequency of $300 \mathrm{rpm}$. In the future, the efficiency remained unchanged (Fig. 3). The results of an increase in efficiency during its running-in are consistent with the findings of other studies [12].

The study of the influence of the rotational speed of the input shaft of the gearbox was carried out in running gear. So, the maximum values of the gearbox efficiency were obtained at a rotation frequency of $300 \mathrm{rpm}$. At rotation speeds of 500, 750, 1000, 1250 and $1500 \mathrm{rpm}$, the efficiency values were $0.78,0.76,0.74,0.72$ and 0.7 , respectively (Fig. 4).

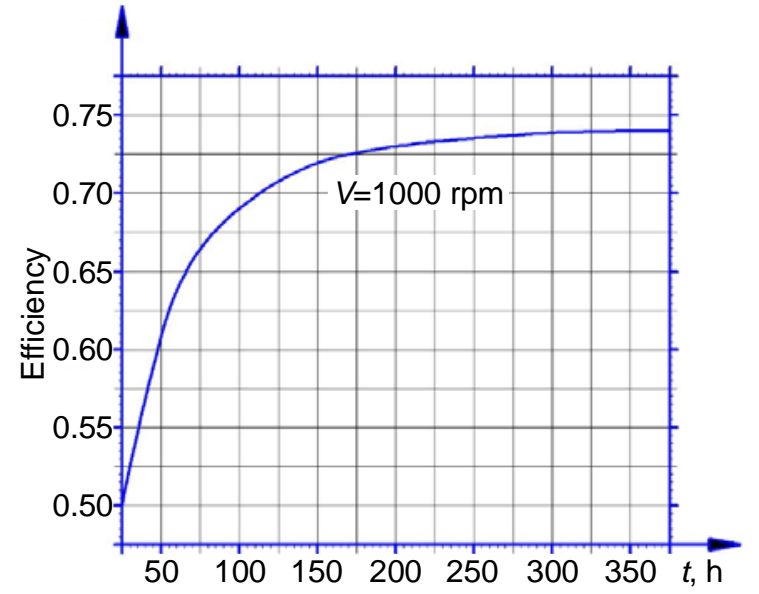

Fig. 3. The dependence of the efficiency on the running-in time of the mechanism

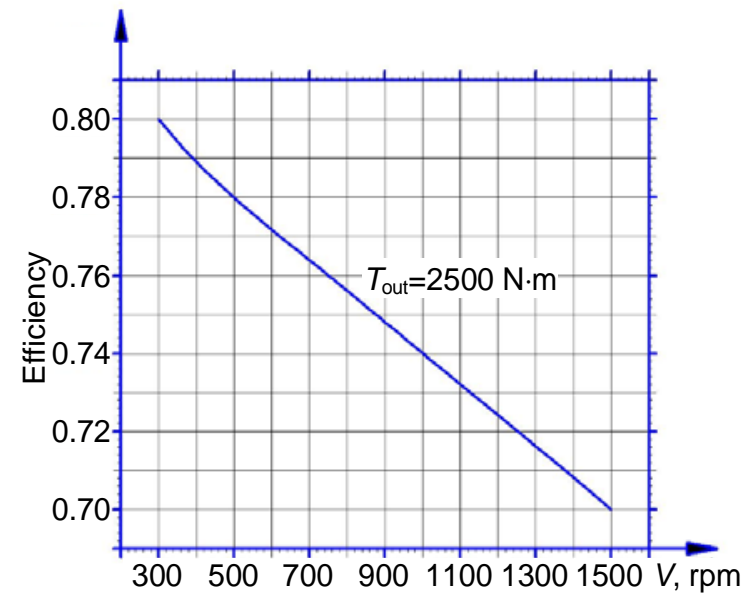

Fig. 4. The dependence of the efficiency on the input shaft speed

A decrease in the efficiency of the transmission under study with an increase in the input shaft rotation frequency is mainly associated with an increase in the sliding speed of the mating links at the contact points of the periodic raceway and the rolling body and a concomitant increase in heat loss.

The results of this study confirm the findings of other studies [12].

The study of the load capacity by loading the gearbox on the test bench showed the ability to transfer design loads with a margin of $25 \%$, further overloading of the mechanism was not performed.

The temperature regime was monitored by measuring the temperature of the housing of a working gearbox using a contact temperature sensor.

Temperature control was carried out by Novatek-Electro PT-100 sensors.

The measurement of temperature during each stage of the running-in transmission showed that with an increase in the degree of running-in, the temperature decreases. This result is consistent with an increase in efficiency during running-in.

During the experiment, it was found that with an increase in the load by $25 \%$ above the nominal, the lubricant temperature practically did not change and was in the range of $60 \ldots 65^{\circ} \mathrm{C}$. From the results of this study, we can conclude that with the adopted load level and the number of revolutions, the created gear has no heating restrictions.

As a result of studies of the noise level, it was found that it was in the range of $50 \ldots 55 \mathrm{dBA}$, and with a decrease in load by $50 \%$ there was a slight increase in noise (18...20\%). Measurements of the noise level were carried out by the sound meter Assistant S - (Auto).

The duration of the entire set of tests was over 400 hours, which corresponds to $3.6 * 107$ cycles.

\section{Conclusions}

Based on our recommendations on the creation of WPGRE, a mechanism with optimized design and technological parameters was designed and manufactured that successfully passed bench tests. During these tests, the operability of the mechanism was confirmed, its efficiency, temperature and noise characteristics were determined, and durability tests were performed. A decrease in efficiency with an increase in the speed of the high-speed shaft was revealed. 
Using the developed design of WPGRE allows:

- reduce material consumption of transmission mechanisms up to 2.7 times in comparison with traditional gears (for example, with a three-stage cylindrical gearbox 1TcZU-200) of similar operational parameters;

- to provide more reliable performance in comparison with wave gears due to the exclusion of the flexible link, the fatigue potential destruction of which is the most likely cause of the failure of the mechanism;

- to provide an increase in the bearing capacity of WPGRE up to $30 \%$ in comparison with existing wave transmissions with rolling element [10 - 12] by increasing the number of rolling element involved in torque transmission (up to $100 \%$ in a single-stage symmetrical WPGRE) [16].

This confirms the rather high technical and economic efficiency of the new gear mechanism and the possibility of their use instead of wave gears.

Below are the comparative characteristics of the created gearbox and the serial manufactured gearbox manufactured by Sumitomo (Japan), as well as the standardized domestic cylindrical gearbox (Table).

Comparative characteristics of gearboxes

\begin{tabular}{c|c|c|c}
\hline Gear unit designation & developed WPGRE & $\begin{array}{c}\text { Sumitomo DRIVE } \\
\text { 6165DB }\end{array}$ & 1 TcZU-200 \\
\hline Manufacturer & LLC “MAGMA” & $\begin{array}{c}\text { Sumitomo Cyclo Drive } \\
\text { Germany GmbH }\end{array}$ & Standardized gearbox \\
\hline Gear type & \multicolumn{2}{|c|}{ The wave with the intermediate rolling ele- } \\
ment & $\begin{array}{c}\text { Cylindrical three-stage } \\
\text { gearbox }\end{array}$ \\
\hline Rated torque on the output shaft & 2500 & 2520 & 2500 \\
\hline Gear ratio & 100 & 104 & 100 \\
\hline Weight & 70 & 87 & 190 \\
\hline
\end{tabular}

Based on the results of experimental studies of WPGRE, the basis for the strength calculation of WPGRE was further developed with optimization of design parameters according to the criteria of minimum contact stresses and uniformity of movement of rolling elements along the periodic raceway.

The conducted experimental studies of the developed mechanism with WPGRE confirmed the legitimacy of using the recommendations we developed on design and manufacturing technology when creating serial analogous drives with high technical and economic performance.

\section{Література}

1. Маргулис М. В. Пути совершенствования приводов машин различного назначения. Вестник Приазовского гос. техн. ун-та. Серия: Техн. науки. 2000. Вып.10. С. 133-138.

2. Янгулов В. С. Волновые передачи с промежуточными телами (состояние, результаты и задачи). Известия Томского политехнического университета. 2007. Т. 311. № 2. С. 14-18.

3. Бубенчиков А. М., Щербаков Н. Р. Математическое моделирование работы эксцентриковой передачи с промежуточными телами качения и самоторможением. Доклады ТУСУРа. 2009. № 1 (19). Часть 1. С. 65-71.

4. Черемнов А. В., Ан И-Кан, Ивкина О. П. Синтез пространственной передачи с промежуточными телами качения с улучшенным качественными характеристиками. Известия Томского политехнического университета. 2012. Т. 321. № 2. С. 26-30.

5. Ефременков Е. А. Разработка и проектирование передач с промежуточными телами качения нового вида. Известия Томского политехнического университета. 2005. Т. 308. № 1. С. 131-135.

6. Янгулов В. С. Силовой расчёт волновых передач с промежуточными телами качения с адаптивным генератором. Известия Томского политехнического университета. 2008. Т. 312. № 2. С. $28-31$.

7. Янгулов В. С. Кинематическая погрешность волновой передачи с промежуточными телами качения. Известия Томского политехнического университета. 2009. Т. 314. № 2. С. 49-54.

8. Янгулов В. С. Геометрические и конструктивные соотношения в волновых передачах с промежуточными телами качения. Известия Томского политехнического университета. 2008. Т. 312. № 2. C. 24-27. 
9. Янгулов В. С., Беляев А. Е. Элементы расчета жесткости волновой передачи с промежуточными телами качения. Известия Томского политехнического университета. 2008. Т. 313. № 3. С. 69-73.

10. Беляев А. Е., Ан И - Кан, Гурин В. В. Механические передачи с промежуточными телами: методические. рекомендации / под общ. ред. А. Е. Беляева. Томск : ТПИ им. С. М. Кирова, 1984. 163 с.

11. Игнатищев Р. М. Синусошариковые редукторы. Минск : Высшая школа, 1983. 107 с.

12. Бостан И. А. Зацепление для прецессионных передач. Кишинев : Штиинца, 1988. 132 с.

13. Передаточный механизм: пат. 92297 Украина. № а200913223; заявл. 18.12.2009; опубл. 11.10.2010, Бюл.№ 19.3 с.

14. Маргулис М. В., Гордиенко Я. О. Разработка оптимизированной методики расчета волновых прецессионных передач с телами качения. Збір-ник наукових праць Вісник Національного технічного університету «ХПІ». Серія: Проблеми механічного приводу. - 2016. № 23 (1195). С. 92-96.

15. Маргулис М. В., Гордиенко Я. О. Разработка прогрессивной высокоэкономичной технологии изготовления волновых прецессионных передач с телами качения. Збірник наукових праць Вісник Національного технічного університету «ХПІ». Серія: Мишинознавство та САПР. 2018. Вип. 25. С.93-97.

16. Передаточный механизм: пат. 109707 Украина: МПК F16H 1/02, F16H 25/06, F16C 3/04, F16C 3/18, F16H 1/28. № a201313359; заявл. 18.11.2013; опубл. 25.09.2015, Бюл. № 18.6 с.

\section{References}

1. Margulies, M. V. (2000). Ways of improvement of different machine-drives. Messenger of Pryazovskyi state technical university. Series: Technical sciences, 10, 133-138.

2. Yangulov, V. S. (2007). Harmonic drives with intermediate rolling elements. Bulletin of the Tomsk polytechnic university, 311 (2), 14-18.

3. Bubenchikov, A. M., \& Scherbakov, N. R. (2009). Mathematical modeling of the operation of eccentric gearing with intermediate rolling elements and self-braking. Proceedings of Tomsk State University of Control Systems and Radioelectronics, 1 (19), 65-71.

4. Cheremnov, A. V., An, I-Kan, \& Ivkina, O. P. (2012). Synthesis of the spatial drives with intermediate rolling elements with improved performance. Bulletin of the Tomsk polytechnic university, 321 (№2), 65-71.

5. Efremenkov, E. A. (2005). Development and design new drives with intermediate rolling elements. Bulletin of the Tomsk polytechnic university, 308 (1), 131-135.

6. Yangulov, V. S. (2008). Force calculation of harmonic drives with intermediate rolling elements with adaptive generator. Bulletin of the Tomsk polytechnic university, 312 (2), 28-31.

7. Yangulov, V. S. (2009). Kinematic error of harmonic drives with intermediate rolling elements. Bulletin of the Tomsk polytechnic university, 314 (№2), 49-54.

8. Yangulov, V. S. (2008). Geometric and structural correlation in harmonic drives with intermediate rolling elements. Bulletin of the Tomsk polytechnic university, 312 (№2), 24-27.

9. Yangulov, V. S., \& Belyaev, A. E. (2008). Calculation of inflexibility harmonic drives with intermediate rolling elements. Bulletin of the Tomsk polytechnic university, 313 (№3), 69-73.

10. Belyaev, A. E., An, I-Kan,, \& Gurin, V. V. (1992). Mechanical transmissions with intermediate ball elements. A. E. Belyaev (Ed.). Tomsk: Tomsk polytechnic university.

11. Ignatischev, R. M. (1983). Sinusoid ball drives. Minsk: Vyisshaya shkola.

12. Bostan, I. A. (1988) Zaceplenie dlja precessionnyh peredach. Kishinev: Shtiinca.

13. Margulis, M. V., \& Mitin, V. V. (2010). Transmission mechanism. Patent 92297, Ukraine.

14. Margulies, M. V., \& Gordienko, Y. O. (2015). The development of optimized methodics of calculation of harmonic precessional drives with rolling elements. Bulletin of NTU "KhPI", 55 (1097), 17-22.

15. Margulies M. V., \& Gordienko Y. O. (2018). The development of the high-efficiency process of manufacturing of harmonic processional drives with rolling elements. Bulletin of NTU “KhPI”, 25 (1301), 93-97.

16. Gordienko, Y. O., \& Margulis, M. V. (2015). Transmission mechanism. Patent 109707, Ukraine.

Маргуліс Михайло Володимирович; Margulies Mykhailo, ORCID: https://orcid.org/0000-0001-6102-5517

Гордіснко Ярослав Олегович; Gordienko Yaroslav, ORCID: https://orcid.org/0000-0002-5216-7502

Received December 25, 2019

Accepted January 27, 2020 